\title{
Improving Students' Reading Ability Through Student Teams Achievement Divisions (STAD)
}

\author{
Santi Wulandari, M. Asrori, Endang Setyaningsih \\ English Education Department \\ Teacher Training and Education Faculty \\ Sebelas Maret University of Surakarta
}

\begin{abstract}
The objectives of this research are: (1) to know whether Student Teams Achievement Divisions (STAD) can improve the students' reading ability and (2) to describe what happens when STAD is implemented in teaching reading in the classroom. This study used a classroom action research design. The participants of this research were the students from one of Junior High Schools in Surakarta, Central Java. There were 32 students which consisted of 14 males and 18 females. The techniques of collecting the data are using qualitative and quantitative data. The qualitative data consists of observation, interview, document analysis, questionnaire, photographs, and test. While the quantitative data was the students' test score. The research findings show that the use of Student Teams Achievement Divisions (STAD) can improve students' reading ability and class condition. It can be seen from their interest and motivation for English class and the mean score of pre-test 57.50 which increased 67.50 in post-test 1 , and 80.16 in post-test 2 . It can be concluded that the use of Student Teams Achievement Divisions (STAD) can improve the students' reading ability and the classroom condition.
\end{abstract}

Key words: reading ability, STAD

\section{INTRODUCTION}

English plays an important role in both written and oral communication. Indonesian students of Junior High School still find difficulties in expressing their ideas in English, because they should be competent to speak, read, write and listen that require their appropriate knowledge on grammar, pronunciation and vocabulary. English teachers are supposed to be facilitators who provide students with knowledge and information that they need, to be guides who help the students solve their problem during the learning process, and to be motivators by creating friendly learning environment.
Reading is one of the four language skills taught in language teaching. Aebersold and Field (1997: 15) define "reading as what happens when people look at a text and assign meaning to the written symbols in that text", it can be concluded that reading is an interactive process that happens between the reader and the text, resulting in comprehension. It means a communication between the reader and the writer. The process involves the reader, the text, the interaction between reader and text. The text presents letters, words, sentences, and paragraphs that encode meaning. The reader uses knowledge, skills, and strategies to determine the meaning. 
Grellet (1998: 7) states "reading is a constant process of guessing, and what one brings to the text is often more important than one finds it". Further, Grellet states "reading as an active skill that constantly involves guessing, predicting, checking, and asking oneself questions". It means that a reader needs background knowledge on the text that they read.

The researcher interviewed 3 students and it revealed the problems. They said that the teaching and learning process was boring and they were not interested in joining the class. The researcher also interviewed the English teacher, she said that she used traditional method and asked the students to do the task in LKS. The reasons for those failures are teacher could not maximize the technique in process reading and thus make the students less motivated.

Those problems on reading indicators and students' motivation are also observable in teaching learning process, the researcher found some indicators dealing with the low of the students' reading ability. The indicators are: the students got difficulty to answer questions in stating the main idea, identifying vocabulary, determining the purpose of the text, identifying the detail information, and finding the reference. The other problem faced by students is motivation. The students are less motivated and are passive. Those problems make the students argue that learning reading is boring, so they tend to be passive in teaching learning process.

Teaching the students of Junior High School is not an easy work. In this case, the teacher should understand the principles of effective teaching reading in order to guide them in choosing the best technique to teach reading.

According to Brown (1994: 7), "teaching is guiding and facilitating learning, enabling the learner to learn, setting the condition of learning. Teacher as a facilitator should be able to facilitate the students". It means that the teacher should facilitate the students with appropriate teaching learning strategy, so that they can learn easily. Burns (1984: 23) says that "enjoyment of reading should be considered as prime importance". In this case, teacher should prove that reading is not a boring activity. Teacher should use an appropriate method and apply various teaching strategy to teach reading that brings the students to enjoyable atmosphere in the class while they learn reading. The appropriate method to teach English can motivate the students to learn.

There are many ways for developing activities in reading class. Cooperative learning is one of the teaching methods that can be applied in teaching reading. Slavin (1995: 2) says "cooperative learning refers to a variety of teaching methods in which students work in small groups to help one another learn academic content". In cooperative classrooms, students are expected to help each other, to discuss and to argue with each other. While Cruickshank (1999: 205) states "cooperative learning is the term used to describe instructional procedures whereby learners work together in small groups and rewarded for their collective accomplishments".

There are general cooperative learning methods adaptable to most subjects and grade levels: Student Teams Achievement Divisions (STAD), Teams Games Tournament (TGT), Team Assisted Individualization (TAI), and Jigsaw II. 
Slavin (1995: 71) defines "STAD is one of the simplest of all cooperative learning methods, and is a good model to begin with for teachers who are new to cooperative approach". Slavin (1988: 395) also says "STAD consists of a regular cycle of teaching, cooperative study in mixed-ability teams, and quiz, with recognition or other rewards provided to teams whose members most exceed their own past records".

Based on the explanation above STAD is one of cooperative learning methods that consist of class presentation, team study, individual quiz, individual improvement and team recognition. Also, STAD can motivate students, encourage and improve each skills presented by the teacher. If the students want their team to get team rewards, they should help their teammates to learn the material taught by the teacher, and also they should encourage their teammates to do their best.

This article discusses the findings of an action research at one of Junior High Schools in Surakarta which has the aim: (1) to know whether Student Teams Achievement Divisions (STAD) can improve the students' reading ability and

(2) to describe what happens when STAD is implemented in teaching reading in the classroom.

\section{RESEARCH METHOD}

This action research was conducted at one of Junior High Schools in Surakarta. The participants of the research were the students of class VII. There were 32 students which consisted of 14 males and 18 females.

This study used a classroom action research design. Action research is the systematic study of efforts to overcome educational problems or to change things related to educational problems for improvement. (Wiersma, 2000)

In this study, the classroom action research was conducted to overcome problems that appear in teaching English. The purpose of the research was to improve the students' reading ability in learning English and could overcome the problem that appears during the teaching and learning process on the class VII from one of Junior High Schools in Surakarta. This research was carried out by the teacher herself as a researcher. The practical action the study use is the technique using Student Teams Achievement Divisions (STAD).

The research was conducted in two cycles. This action research consisted of planning, action, observation, and reflection. There were two types of data, they are: qualitative data that are obtained by conducting interview, observation, questionnaire, and test; meanwhile quantitative data were obtained from the students' scores of pretest and post-test.

\section{RESEARCH FINDINGS AND DISCUSSION}

In this research the researcher implemented Student Teams Achievement Divisions (STAD) as a method to improve student's reading ability. The research was conducted in two cycles. There were three meetings held in each cycle. The researcher used three meetings in each cycle to implemented the steps of STAD.

The researcher conducted post test 1 at the end of cycle 1 in order to know and to measure how far was the 
improvement that the students made. The improvement of the students' achievement could be seen in the mean score of post test 1 .

It could be concluded that the cycle 1 showed improvement of students' reading ability but it was still far from expected result. The researcher thought that it was necessary to conduct cycle 2 with a revised plan. It was also needed to overcome the weaknesses in cycle 1.

The students still had difficulties in identifying detail information, reference and meaning. The researcher would give brainstorm to them, find the difficult words in a text, and give some more example and exercises using Power Point so they could focus in the lesson.In cycle

2 the researcher made sure the students give their opinion while in a team. Because if they did not understand about the lesson then just kept silent, they could not answer the individual quiz 2 . The researcher would make the students to answer the question by asking the students who had the student's number that matched by the date. Then if she or he finished answer the question, for the next question, she or he should appoint the other students who had different gender from her or him to answer the question.

The researcher conducted post test 2 at the end of cycle 2 in order to know and to measure how far the improvement that had been made by the students was. The improvement of the students' achievement could be seen in the mean score of post test 2 .

After conducting two cycles of this research, the researcher finally could compare dealing with what happened before and after the action research implemented. According to the result of final observation and final test of the research, there were some improvements and developments in some areas or aspects. Both the students' reading ability and the condition of the class in learning process got progress. By observing the teaching and learning process, the students showed their interest and followed the teaching learning process more enthusiastic. They paid more attention to the lesson and the researcher's explanation. When the students worked in team, not only they interacted with their friends but also they were brave to ask the difficulties with the researcher. They discussed the lesson actively in their team and helped each other to answer the task. In this cycle, the researcher saw that there was a good cooperation in each team. Also, the students found the difficult words together, they tried to guess. If the students were not sure about the meaning, they opened the dictionary to find the meaning. They were more responsible to their teams. The last, most of the students were brave to answer the question from the researcher.

The students' behavior also played role in increasing of test score.The researcher found that teaching reading using Student Teams Achievement Divisions (STAD) made the students more motivated in teaching learning process, especially in learning reading. There were some students who had low achievement and the students who had high achievement in a team. So that, the students who had high achievement help, explain and teach their friends who had low achievement. Each team had responsibility about their teammates' understanding, so they did the individual 
quiz well. All of the students felt motivated and enthusiastic to join the class, because by using STAD they could ask exchange and share their ideas together in the class while they did discussion with their teammates. There was no student who felt sleepy, because they enjoyed the class and paid more attention to what happened in the class. The class was being noisy, but it was from discussion in each team. Actually, the students were happy to work together, so they were cooperated each other to have correct answer of the questions.

Based on the description of those two cycles, the researcher concluded that the use of Student Teams Achievement Divisions (STAD) had improved students' reading ability. The indicators of reading ability concerned in this research could be improved. The indicators of reading ability were: stating the main idea, identifying vocabulary, determining the purpose of the text, identifying the detail information, and finding the reference. After implementing STAD method in the process of teaching and learning reading activity, the students' reading ability could improve. It is proved from their achievement which had been increasing step by step in six meetings of teaching and learning activity. It can be inferred that STAD could help them to improve their reading ability. This statement is supported by Kessler (1992:7) that cooperative learning provides increased interactions between students. It organizes team work to improve learning and increase academic achievement.

By utilizing the stage of STAD method, the students could improve their reading ability gradually. As the result, the students could reach better achievement as what has been described in the research findings section. The improvement could be shown from the students' achievement scores. The mean score was increased from 57.50 in the first test to 67.50 in the second test and it increased significantly to 80.16 at the third test.

In summary, the use of STAD can improve the students' reading ability of class VII fromone of Junior High Schools in Surakarta. The students could state the main idea, determine the purpose of the text, identify detail information, guess the meaning and find reference.

By using STAD method, there were a lot of changes from the previous condition in the class. The changes caused by STAD were positive change. The students' behavior got better. This high learning motivation from the students had changed many things dealing with the class condition in the process of teaching and learning activity. The students had been more motivated to join the class. The students paid more attention to the researcher's presentation about descriptive text that used Power Point slideshow. So, there were no more students who disturbed the teaching and learning process.

During the teaching and learning process, the students were more actively involved in each activity. If they discussed in a team and found any difficulties, the students directly raised their hands and asked the question to the researcher. They enjoyed to discuss and share with their teammates. Team members gained a better understanding of themselves because they interacted with their teammates. In doing individual quiz they looked serious and focused to do the quiz. In individual improvement step and team recognition, they looked satisfied because 
their scores were improved.

Based on the explanation above, it could be shown that Student Teams Achievement Divisions (STAD) can improve the class condition that was shown from the students' behavior in the class during the teaching and learning process.

\section{CONCLUSIONS AND SUGGESTIONS}

Having analyzed the data, the result of the research findings about the implementation of Student Teams Achievement Divisions (STAD) in improving students' reading ability in learning English of Junior High School students, conclusion can be drawn. Those conclusions at once answers the research questions listed in chapter 1: (1) to know whether Student Teams Achievement Divisions (STAD) can improve the students' reading ability and

(2) to know what happens when STAD is implemented in teaching reading in the classroom.

First, the data indicate that STAD can improve reading ability of the students. Statistically, the students' reading achievement mean score increased from 57.50 in the pre-test to 67.50 in the post-test 1 and rose to 80.16 in post test 2 . The mean score gain reflects the improvement in each reading indicator. All indicators improve from test to test. Calculated sing matched t-test formula, the result between pre-test and post test 2 was 19.79. It means that the increase can be accounted due to the intervention (the STAD implementation).

Second, STAD promotes enjoyable and interesting atmosphere in the classroom. Using STAD, particularly in step team study, the students learn the material through cooperation, working together with their friends without being shy or afraid. Students gave more attention and show their interest to the researcher's explanation because their English teacher never used Power Point slide show to teach English, so it attracted their interest. They are also brave to ask questions when they found difficulties. In a nutshell, the students began to actively participate in the learning activities; and they were very enthusiastic in doing all tasks.

After concluding the result of the study, the researcher would like to propose some suggestions. In this study, there were some students who gave more attention to the teacher's explanation and they were being actively in team study. But, for implementing STAD, it needs 3 meetings so that the teacher should able to manage the time. Then, the teacher should use power point slide show so that students could gave more attention and focus to the teacher's explanation. The students said that it was the first time for them taught by power point slide show.

This study discusses the implementation of Student Teams Achievement Divisions (STAD) method to teach reading in Junior High School Level. Further study can be conducted in different subject area and level of students. Besides, different method can be applied to examine the use of STAD,

e.g. comparing the experimental groups of students taught using STAD in different (and wider) areas; developing a model for effective grouping, etc. 


\section{BIBLIOGRAPHY}

Aebersold, Jo Ann \& Field, Marrie Lee. 1997. From Reader to Reading

Teacher.

United Kingdom: Cambridge University Press.

Arends, Richard. I. 1997. Classroom and Management. Boston: McGraw Hill. Burns, Paul C. Roe. Betty D \&Ross.Elinor P. 1984. Teaching Reading in Todays

Elementary Schools. Boston: Horgton Mifflin Company Boston.

Brown, H. Douglas. 1994. Principlesof Language Learning and Teaching. New Jersey: Prentice Hall.

Cruickshank, Donald R., et al. 1999. The Act of Teaching. Boston: McGrawHill Companies, Inc.

Grellet, Francouis. 1998. Developing Reading Skills: A Practical Guide to Reading Comprehension Exercise. Cambridge: Cambridge University Press.

Kessler, Carolyn. 1992. Cooperative Language Learning. New Jersey: Prentice Hall

Slavin, Robert E.1988.Educational Psychology: Theory into Practice. $\left(2^{\text {nd }} e d\right)$. United States: Allyn and Bacon.

Slavin, Robert E. 1995.Cooperative Learning. Massachusetts: Allyn and Bacon. Wiersma, William. 2000. Research Methods in Education: An Introduction.

Boston: Allyn and Bacon. 